\title{
Przyszłość prawa pracy z perspektywy istniejących dla niego zagrożeń
}

Prawo pracy to przede wszystkim określony zespół norm prawnych, w tym zwłaszcza tych, które znajdują się w obowiązującym Kodeksie pracy. W związku z tym można sformułować tezę, że dopóki kodeks ten obowiązuje, to byt prawa pracy w znaczeniu normatywnym nie jest $\mathrm{w}$ żadnej mierze zagrożony. Oczywiście odrębność prawa pracy jako osobnej gałęzi prawa uległaby znacznemu podkreśleniu i umocnieniu, gdyby udało się uchwalić projekty Kodeksu Pracy oraz Zbiorowego Kodeksu Pracy po odpowiednim dostosowaniu zawartych w nich propozycji do warunków zmienionych od czasu, jaki upłynął od zakończenia prac przez Komisję do spraw kodyfikacji prawa pracy, powołanej na lata 2002-2006. Nie znaczy to wszakże, że prawo pracy jako wyodrębniona całość nie jest wystawione na różnego rodzaju zagrożenia, a ponadto jest jasne, że musi się ono stale dostosowywać do zmieniających się uwarunkowań społeczno-gospodarczych i politycznych oraz krajowego i unijnego (międzynarodowego) kontekstu normatywnego. W zależności przy tym od wielu czynników może być ono w lepszym bądź gorszym stanie; mówiąc obrazowo - może rozkwitać lub marnieć.

Wśród różnych zagrożeń dla bytu i stanu (dobrostanu) prawa pracy wyróżnić należy zwłaszcza zagrożenia o charakterze głębszym, wynikające przede wszystkim z przekształcania się stosunków gospodarczych, zmiany sposobów gospodarowania i wytwarzania oraz wzrostu poziomu sił wytwórczych. Obok tego ważne są zagrożenia, które można określić jako ideologiczno-doktrynalne.

Prawo pracy jest produktem kapitalizmu, a ten efektem rewolucji przemysłowej. Rozwój myśli technicznej (wynalazczość, nowa technika i nowe technologie) doprowadził do powstania fabryk i nowych metod wytwórczości, będących następstwem nowych sposobów wykorzystania, zwłaszcza pary, elektryczności, ropy naftowej i gazu. Oznaczało to ukształtowanie się

* Prof. zw. dr hab., Wydział Prawa i Administracji Uniwersytetu w Białymstoku, sędzia Sądu Najwyższego w stanie spoczynku, Prezes Sądu Najwyższego w latach 2001-2013. 
nowych stosunków przemysłowych, a w konsekwencji także nowych stosunków społecznych i politycznych. Nowa organizacja pracy (praca fabryczna) zrodziła zapotrzebowanie na nowe formy (konstrukcje) prawne, co doprowadziło do pojawienia się nowego typu umowy, a mianowicie umowy o pracę, stanowiącej przekształconą formę umowy o świadczenie usług (umowy zlecenia). Organizacja fabryczna to nowe zasady kooperacji, wyrażające się w konieczności większej dyscypliny i podporządkowania. Na tle innych umów, znanych jeszcze z czasów rzymskich, umowę o pracę wyróżnia przede wszystkim wyraźna możliwość sprawnego, dyktowanego przez reżym pracy fabrycznej, sterowania zachowaniem pracowników $\mathrm{w}$ procesie pracy, wyrażająca się zwłaszcza w uprawnieniu pracodawcy do wydawania im poleceń. Ta nowa umowa stała się osią prawa pracy i jest nią do dnia dzisiejszego. Nowe stosunki produkcji stanowiły - z jednej strony - przyczynę gwałtownego skoku cywilizacyjnego, ale jednocześnie -z drugiej strony - stały się źródłem nieznanych wcześniej zjawisk i problemów, w tym zwłaszcza takich, jak wyzysk pracowników. Zmusiło to państwa do interwencji, która znalazła wyraz w regulacjach tzw. ochronnego prawa pracy, a jednocześnie doprowadziło do pojawienia się ruchów stanowiących rodzaj samoobrony klas wyzyskiwanych, przejawiających się w powstaniu związków zawodowych i robotniczych partii politycznych. Czynnikiem, który determinuje sposoby wytwórczości, są przede wszystkim wynalazki (nowa technika i technologia), a te z kolei decydują o kształcie stosunków gospodarczych i stosunków społecznych oraz politycznych. Oczywiście wynalazki nie biorą się znikąd i zależą od różnych uwarunkowań. O współczesnych społeczeństwach mówi się nieraz, że są społeczeństwami postindustrialnymi. W coraz większym stopniu zastosowanie ma w nich technika i technologie elektroniczne czy środki i usługi elektroniczne. Pojawia się więc pytanie, czy w tych nowych warunkach istnieje i będzie istniało zapotrzebowanie na pracę podporządkowaną $\mathrm{i}$ umowę o pracę. W moim przekonaniu, mimo obserwowanych zmian sił wytwórczych i stanowiących ich następstwo zmian sposobów organizacji pracy, w dającej się przewidzieć przyszłości zapotrzebowanie na umowę o pracę i tym samy na prawo pracy, nie zniknie. Trudno przewidywać, że konsekwencją rewolucji elektronicznej i automatyzacji produkcji będzie brak zapotrzebowania na pracę podporządkowaną czy też radykalna jego marginalizacja. Na razie większość zatrudnionych ma nadal status pracowników umownych, a przy tym z uwagi na skalę utrzymującego się bezrobocia walczy o jego zachowanie bądź uzyskanie (odzyskanie), co świadczy o tym, że poziom napięć i konfliktów w stosunkach przemysłowych (gospodarczych) ciągle jest wysoki i w związku z tym wymaga interwencji, a co najmniej czujności i reakcji ze strony państwa. W nowych warunkach nie znika też potrzeba ochrony interesów pracowników przez ich organizacje, a więc istnienia pewnego rodzaju ich zbiorowej (zorganizowanej) samoobrony. 
Niezależnie od tego nie należy uciekać od pytania, czy taki stan rzeczy będzie trwał wiecznie i czy rewolucja elektroniczna (z zalążkami rewolucji kosmicznej) nie doprowadzi w przyszłości do tak radykalnych zmian w organizacji pracy wytwórczej (w tym w usługach), że zmarginalizowane zostanie zapotrzebowanie na pracę podporządkowaną i tym samym na umowę o pracę. Gdyby marginalizacja taka nastąpiła, to - choć trudno wyobrazić sobie, że umowa ta w ogóle zostałaby wyeliminowana $\mathrm{z}$ porządku prawnego - oznaczałoby to postawienie istnienia prawa pracy, jako osobnej gałęzi prawa, pod znakiem zapytania. Pamiętać jednak także warto, że podstawowym instytucjom prawa cywilnego (własność i inne prawa rzeczowe, umowa kupna sprzedaży i inne umowy) nie zaszkodziło to, że ukształtowane zostały w warunkach wytwórczości niewolniczej. Przetrwały bowiem feudalizm i realny socjalizm oraz dobrze sprawdzają się w kapitalizmie. Podobnie odejście od zasad gospodarki rynkowej w czasach PRL nie spowodowało unicestwienia umowy o pracę i całego prawa pracy, a raczej - wręcz przeciwnie - doprowadziło po 1956 r. do jego rozwoju, czego techniczno-legislacyjnym wyrazem było zwłaszcza uchwalenie w 1974 r. Kodeksu pracy.

Rewolucja informatyczna zmieniła i zmienia oblicze świata, przenikając wszystkie sfery bytowania ludzkiego. Stanowi ona następstwo gwałtownego przyspieszenia wynalazczości, która doprowadziła do pojawienia się komputerów, telefonów komórkowych, internetu, urządzeń elektronicznego przesyłania danych na odległość (GPS, światłowody) i innych zupełnie nowych rozwiązań technicznych i technologicznych. Nastąpiły i następują zasadnicze zmiany w metodach produkcji przemysłowej, gdyż rewolucja informatyczna umożliwiła pełniejszą jej automatyzację i robotyzację, a w przyszłości zapewne upowszechni produkcję dóbr materialnych przez drukarki. Zmiany nastąpiły i następują także w sferze usług materialnych i niematerialnych, w szczególności usług kapitałowych, bankowych, giełdowych, handlowych, co w dużej mierze jest następstwem pojawienia się pieniądza elektronicznego. Rewolucja informatyczna pociąga za sobą konsekwencje polegające na zmianach stosunków gospodarczych, ale także społecznych, w tym w sferze ideologii, kultury, religii, sportu, obyczajowości, jak również stosunków politycznych i to zarówno w wymiarze krajowym, jak i międzynarodowym. Przyczyniła się zarazem i przyczynia do przyspieszenia procesów globalizacyjnych. Pociąga za sobą zmianę metod i sposobów organizowania pracy we wszystkich dziedzinach, nie tylko w gospodarce, ale także $\mathrm{w}$ aparacie publicznym (w sferze usług wykonywanych przez państwo). Nic więc dziwnego, że rewolucja informatyczna zmienia także prawo pracy. Obserwowanie istniejącej i dającej się przewidzieć rzeczywistości prowadzi do wniosku, że jej konsekwencje w sferze tego prawa, choć widoczne 
$\mathrm{i}$ istotne, oznaczają jedynie jego zmianę, a nie likwidację, bo także w warunkach organizacji pracy wymuszanej przez postęp informatyczny istnieje zapotrzebowanie na pracę podporządkowaną i, co więcej, również $\mathrm{w}$ tej zmienionej czy zmieniającej się rzeczywistości głównym rodzajem zatrudnienia jest zatrudnienie $\mathrm{w}$ ramach stosunku pracy. Rewolucja informatyczna stanowi więc zagrożenie dla egzystencji prawa pracy, ale nie prowadzi do jego anihilacji.

Postęp cywilizacyjny spowodowany przez rozwój kapitalistycznych stosunków produkcji (gospodarowania) w zasadniczy sposób wpłynął nie tylko na rewolucyjną zmianę stosunków społecznych (w tym na ideologię, kulturę i obyczajowość), ale także na sposób organizowania aparatu państwowego i określania zadań państwa. Postęp cywilizacyjny sprawił, że w państwach kapitalistycznych - także w tych, które realizowały zasady tzw. państwa stróża nocnego - w sposób zasadniczy wzrósł zakres i rodzaj zadań realizowanych przez aparat państwowy; były to nowe zadania o charakterze socjalnym (w tym edukacyjnym), ale także w inny sposób i na inną skalę realizowane były przez te państwa zadania w zakresie zapewnienia bezpieczeństwa wewnętrznego i zewnętrznego. Sprawiło to, że zaczęto zatrudniać dziesiątki tysięcy, a następnie miliony urzędników $\mathrm{i}$ innych funkcjonariuszy publicznych.

W tym stanie rzeczy, stanowiącym zmianę jakościowa, zaszła potrzeba nowego zorganizowania pracy ich wszystkich. Nie wystarczyły formy znane i wypróbowane $\mathrm{w}$ feudalizmie, trzeba było znaleźć nowe rozwiązania prawne, które określane bywają jako nowożytne prawo urzędnicze czy prawo służby publicznej. Wielość i złożoność zadań państwa w nowych warunkach, przy idącym w miliony zatrudnieniu funkcjonariuszy służby publicznej, zrodziły zapotrzebowanie na taką organizację ich pracy, która gwarantowałaby rzeczywiste i sprawne wykonywanie zadań państwa i wymagała wysokiej dyscypliny oraz ścisłego wykonywania poleceń, a w ogólności szczególnego (podwyższonego) stopnia podporządkowania państwu jako podmiotowi zatrudniającemu. Doprowadziło to do powstania osobnego, obok statusu pracowniczego (umowy o pracę), statusu służby publicznej, powstającego w wyniku mianowania na stanowisko), który miał charakter publicznoprawny (administracyjnoprawny). Następnie jednak demokratyzacja ustrojów państwowych sprawiła, że tradycyjny model służby państwowej (ukształtowany na przełomie wieków XVIII i XIX) współcześnie stanął pod znakiem zapytania. Zakres i ciężar zadań obciążających (przyjmowanych na siebie) państwa nie zmalały, a wręcz przeciwnie wzrosły, co nie znaczy, że w zmienionym kontekście ustrojowym, społecznym, gospodarczym, politycznym, a także technicznym i technologicznym, zadania te mogą być dobrze realizowane tylko przy przyjęciu tradycyjnego, publicznoprawnego modelu służby publicznej 
(prawa urzędniczego), rodzącego zjawisko kastowości urzędniczej i przesadnie wysokich wymagań w zakresie urzędniczego podporządkowania oraz ograniczeń swobód prywatnych i obywatelskich.

W naszym kraju - pomijając służby mundurowe - odeszliśmy od opisanego modelu doprowadzając do tego, że zasadą jest zatrudnienie $\mathrm{w}$ aparacie państwowym na podstawie umowy o pracę, przy ograniczeniu zatrudnienia na podstawie mianowania i z jednoczesnym nadaniem stosunkowi prawnemu, który z niego wynika, charakteru stosunku zobowiązaniowego (prywatnoprawnego), a nie publicznoprawnego. Dla sprawnego, prawidłowego i skutecznego realizowania zadań państwa wystarczająca jest konstrukcja zobowiązaniowego stosunku pracy i nie ma potrzeby podwyższania stopnia i zakresu podporządkowania oraz uzależniania od państwa (pracodawcy) - w wymiarze większym niż to wynika ze stosunku pracy - osób zatrudnionych w aparacie publicznym. Co więcej, służba publiczna $\mathrm{w}$ naszym kraju do pewnego stopnia stała się bastionem prawa pracy. Nie sądzę, by rewolucja elektroniczna wymusiła potrzebę na tyle nowej organizacji pracy w aparacie publicznym, że przestanie istnieć $\mathrm{w}$ nim zapotrzebowanie na prawną konstrukcję podporządkowania pracowniczego i tym samym stosunku pracy. Nie można wszakże wykluczyć, że zagrożenie takie pojawi się w odleglejszej przyszłości. We współczesnych realiach nie ma też powodów i rzeczywistej potrzeby wracania $u$ nas do tradycyjnego modelu prawa służby publicznej (prawa urzędniczego), opartego na publicznoprawnym charakterze zatrudnienia $w$ aparacie publicznym. Nie widzę też warunków do prywatyzacji zatrudnienia $\mathrm{w}$ aparacie publicznym przez zastąpienie $\mathrm{w}$ nim umowy o pracę i mianowania (a także powołania i wyboru na stanowisko) umowami cywilnoprawnymi (umową o świadczenie usług, umową zlecenia, umową o dzieło), czy też tzw. samozatrudnieniem (świadczeniem usług przez podmioty gospodarcze w zakresie wykonywania zadań państwa, zlecenia im ich przez państwo). Sądzę, że zjawisko zatrudnienia niepracowniczego - poza służbami zbrojnymi - oraz samozatrudnienia w aparacie publicznym $\mathrm{w}$ najbliższym, dającym się przewidzieć czasie będzie istniało, ale będzie miało marginalny zakres i znaczenie. Tym samym brak jest poważniejszych zagrożeń dla przyszłości prawa pracy w aparacie publicznym (pracowniczego zatrudnienia $\mathrm{w}$ administracji publicznej i w pozostałych działach służby publicznej, np. w szkolnictwie czy wymiarze sprawiedliwości).

Wśród różnych zagrożeń dla prawa pracy wyróżnić można i należy także zagrożenia o charakterze historycznym. Mam tu na myśli zwłaszcza zagrożenia związane z okresem stalinowskim oraz z rozwojem koncepcji samorządu pracowniczego. Swoistość tych zagrożeń polegała szczególnie na tym, że były one wynikiem i jednocześnie wyrażały się w forsowaniu 
określonych tez ideologicznych i doktrynalnych ale zarazem znalazły odbicie w konkretnej praktyce społeczno-gospodarczej i politycznej. W Polsce okres tych zagrożeń przypada głównie na lata 1950-1956 (okres stalinowski), kiedy zaczęto przebudowywać prawo pracy w myśl idei stalinowskich. System polityczny oparty został na dominacji (hegemonii) jednej partii, system gospodarczy skrajnie scentralizowano (możliwe to było w efekcie upaństwowienia środków produkcji), a system stosunków społecznych zetatyzowany (stosunki społeczne poddano daleko posuniętej ingerencji ze strony państwa). W sposób zasadniczy, w wyniku wprowadzenia nakazów pracy, została ograniczona zasada wolności zawierania umów o pracę, w tym zasada wolności pracy. Nakaz taki jako akt administracyjny rodził stosunek pracy albo był równoznaczny z zakazem jego rozwiązania przez określony czas. Naruszenie nakazu było zagrożone sankcjami, w tym sankcją typu karnego. Ustanowiono rygorystyczne reguły tzw. socjalistycznej dyscypliny pracy, zaniechano zawierania układów zbiorowych pracy, a sytuacja związków zawodowych ukształtowana została w myśl zasady, że stanowią one transmisję programu partii do mas. Oznaczało to w konsekwencji, że potraktowano je głównie jako organizacje powołane do realizowania zadań państwa, a nie do ochrony praw i interesów pracowników. Zostały one w ten sposób niejako upaństwowione - przez przyjęcie założenia, iż ich pierwszoplanowym celem jest wykonywanie zadań zleconych przez państwo. Nic też dziwnego, że w owym czasie regulacje prawne dotyczące związków zawodowych traktowane były jako część prawa administracyjnego (publicznego). Przekazano im w pewnym zakresie uprawnienia prawodawcze (wytyczne Centralnej Rady Związków Zawodowych traktowane były jako akty normatywne), uprawnienia władzy wykonawczej (powierzono im sprawowanie inspekcji pracy, przekazano administrację świadczeń zasiłkowych z ubezpieczenia społecznego), a także władzy sądowniczej (np. zarządy główne związków zawodowych, w charakterze organów sądowych, rozpoznawały odwołania od orzeczeń komisji rozjemczych). Dokonywane to wszystko było pod hasłem wzmocnienia roli związków zawodowych jako organizacji społecznych, ale w praktyce prowadziło do ich swoistego „upaństwowienia” i zbiurokratyzowania. Jednocześnie zapewnienie pracy pracownikom (ich prawo do pracy) traktowane było zasadniczo jako powinność państwa, a nie ich prawo podstawowe (prawo człowieka wynikające z godności osoby ludzkiej).

Dalsze zmiany regulacji prawa w tym kierunku mogły grozić przeistoczeniem się prawa pracy w część prawa administracyjnego (publicznego), gdzie pracownik (jego siła robocza) staje się bez mała własnością państwa, a główną racją jego istnienia jest realizowanie zadań tego państwa, w zasadniczych zarysach ustalanych przez partię rządząca, a szcze- 
gółowiej przez administrację państwową. Mogły one też doprowadzić do przekształcenia się stosunku pracy w stosunek prawny o charakterze publicznoprawnym (administracyjnoprawnym) i do zaniku umowy o pracę jako czynności prawnej rodzącej więź zobowiązaniową. Na szczęście dalszy rozwój stosunków politycznych i społeczno-gospodarczym, a także rozwój prawa pracy w naszym kraju potoczył się w innym kierunku. Po 1956 r. zniesione zostały nakazy pracy i ustawa o socjalistycznej dyscyplinie pracy, przywrócono praktykę zawierania układów zbiorowych pracy i wzmocniono rolę umowy o pracę oraz zasady wolności pracy. Ograniczono też ten zakres zadań związków zawodowych, które można było traktować jako zadania państwa (tzw. zadania produkcyjne). Na szczęście zagrożenie, jakie dla prawa pracy niósł ze sobą system stalinowski - podobnego typu uwagi dotyczą także ustrojów nazistowskich, w których również, pod hasłem działania w ich interesie, w pracownikach widziano przede wszystkim siłę roboczą służącą realizacji zadań i interesów państwa - należy już do przeszłości. System stalinowski okazał się niewydolny gospodarczo oraz społecznie. Oparty był na utopijnych założeniach i możliwy do wprowadzenia w określonych warunkach tylko dzięki skupieniu i dysponowaniu potężną siłą polityczną oraz użyciu na dużą skalę przemocy.

Innego rodzaju zagrożenia dla prawa pracy wynikały z koncepcji samorządności pracowniczej. W skrócie można powiedzieć, że groziło mu rozmycie w prawie samorządowym. Koncepcja samorządowej organizacji wszystkich zasadniczych struktur państwowych w praktyce w sposób pełny i konsekwentny realizowana była swego czasu w Jugosławii. W sferze zatrudnienia $\mathrm{w}$ pewnym stopniu prowadziła ona do zanegowania umowy o pracę jako podstawy stosunku pracy. Wprawdzie w jej ramach $\mathrm{z}$ umowy tej $\mathrm{w}$ sensie pojęciowym i konstrukcyjnym w całości nie zrezygnowano, ale znamienne i ważne było zastąpienie kategorii pracodawcy pojęciem organizacji pracy zespolonej. U jej podłoża leżała myśl, że pracownicy sami są dla siebie pracodawcami. Warsztat pracy stanowi ich wspólna własność, wobec tego sami zarządzają procesami pracy w sposób zbiorowy. Można powiedzieć, że przy takich założeniach mieliśmy do czynienia z samozatrudnieniem, tyle tylko, że kolektywnym. Jeżeli zaś jest to kolektywne samozatrudnienie, to nie bardzo jest miejsce na tworzenie prawa ochronnego i związków zawodowych, bo oznacza to ochronę przed samym soba, tj. przed decyzjami podejmowanymi wspólnie, kolektywnie, przy założeniu, że wpływ wszystkich członków zespołu na te decyzje jest rzeczywisty, a nie pozorny. System ten oparty był na założeniu braku antagonizmu między pracą i kapitałem, co - z jednej strony - można uznać za założenie szczególnie szlachetne i humanistyczne, z drugiej wszakże - okazało się ono utopijne. Jugosłowiański system samorządu 
pracowniczego, podobnie jak system stalinowski, a także późniejszy system tzw. gospodarki nakazowo-rozdzielczej, okazały się w zderzeniu $\mathrm{z}$ gospodarką rynkową niewydolne i w związku z tym musiały upaść. Wraz z ich upadkiem przestały również istnieć zagrożenia dla prawa pracy, jakie one ze sobą niosły.

Zagrożenia ideologiczno-doktrynalne mają - co zrozumiałe - mniejsze znaczenie, tym niemniej nie należy ich pomijać. Dotyczy to zwłaszcza poglądów ekonomicznych, które można określić jako skrajnie liberalne. Wyrażają się one zwłaszcza w tezie, że prawo pracy, w tym zwłaszcza Kodeks pracy, stanowi nieuzasadnioną przeszkodę w rozwoju gospodarczym naszego kraju. Prowadzą bowiem do podnoszenia tzw. kosztów pracy, które są przez to nadmierne oraz osłabiają efektywność i konkurencyjność gospodarki w wymiarze europejskim i światowym. Krytyka prawa pracy wyraża się między innymi w stwierdzeniu, że mając tak „skandaliczny" Kodeks pracy, jak ten który obowiązuje, kraj nie może się normalnie rozwijać. Towarzyszy temu oczekiwanie, że kodeks ten zostanie uchylony, a wraz z nim ochrona pracowników, którą przewiduje.

Nie jest jednak do końca jasne, czy zwolennicy tego poglądu są zdania, że wraz z uchyleniem „skandalicznego" Kodeksu pracy należy także wyeliminować umowę o pracę i zrezygnować z podporządkowania pracownika pracodawcy (władzy pracodawcy), które ona przewiduje, i czy wobec tego $\mathrm{w}$ istniejących warunkach jest możliwa taka organizacja produkcji i usług, która obywa się bez tego elementu. Przypuszczam wszakże, że zwolennicy uchylenia Kodeksu pracy nie zamierzają jednocześnie domagać się likwidacji podporządkowania pracowniczego i tym samym umowy o pracę oraz oparcia zatrudnienia jedynie na umowie zlecenia, umowie o dzieło i innych umowach o świadczenie usług. Jeżeli tak, to powinni uwzględnić fakt, że ochrona pracownika przewidziana przez prawo pracy (tzw. koszty pracy z nią związane) jest konsekwencją czy raczej swoistą ceną jaką pracodawcy muszą zapłacić za ograniczenie wolności pracownika wynikające $\mathrm{z}$ tego, że zobowiązuje się on nie tylko do wykonywania pracy na rzecz pracodawcy, ale że decyduje się także na to, iż będzie ona świadczona $w$ reżymie podporządkowania pracodawcy i, szerzej, władzy pracodawcy (np. możliwości nakładania przez niego kar porządkowych).

W ostatnim czasie pojawiają się z jednej strony tezy, że prawo pracy w całości jest prawem publicznym, a związki zawodowe wykonują zadania administracji publicznej, które zostają im zlecone, z drugiej strony wyrażane są sugestie, że czas już, by prawo pracy przekształciło się w prawo zatrudnienia, co oznaczałoby, że jądrem oraz podstawowym pojęciem i konstrukcją tego prawa nie jest umowa o pracę i stosunek pracy. Są nim natomiast inne formy zatrudnienia, takie jak umowy o świadczenie usług 
czy samozatrudnienie, a $\mathrm{w}$ każdym razie powinny być one traktowane na równi z umową o pracę. Dochodzą do tego pomysły, by za osobną gałąź prawa uważać raczej prawo socjalne, obejmujące klasyczne prawo pracy i prawo zabezpieczenia społecznego. Pierwszy z wymienionych poglądów nie bierze pod uwagę np. walki, jaką w czasach stalinowskich trzeba było stoczyć w obronie zobowiązaniowego charakteru stosunku pracy (zobowiązania prawa pracy) przed tendencjami zmierzającymi do jego „upaństwowienia” i „publicyzacji” oraz chęcią likwidacji zasady wolności pracy, a także włączenia związków zawodowych w orbitę zadań państwowych.

Pracownik i związki zawodowe nie są po to, by realizować interesy i zadania państwa i w związku z tym nie mogą być traktowane jako podmioty prawa administracyjnego (publicznego) lub też jako podmioty realizujące zadania zlecone, które powierza im do wykonania władza publiczna czy administracja państwowa. Związki zawodowe mają bronić praw i interesów pracowników, a nie wykonywać zadania zlecone im przez administrację państwową i to niezależnie pod tego, co na ten temat sądzi ta administracja i czy odpowiada to jej wizji państwa i jego zadań. Zdawać należy przy tym sobie sprawę, że teza o publicznym charakterze całego prawa pracy może prowadzić w konsekwencji do uznania, iż także umowa o pracę i stosunek prawa pracy mają charakter publicznoprawny (administracyjnoprawny), a nie zobowiązaniowy, a stąd wiedzie już krótka droga do rozwiązań ograniczających wolność zatrudnienia i ustanawiania przymusu pracy w imię wyższych celów państwowych (ustalanych przez administracje państwową) czy też administracyjnie pojętego dobra wspólnego. Prawo pracy jako kategoria pojęciowa i normatywna nie może być w całości uznana za część prawa publicznego (administracyjnego), choć jako dyscyplina kompleksowa zawiera także przepisy mające naturę administracyjnoprawną. Podobnie też w całości nie należy do prawa cywilnego (prywatnego), jakkolwiek jego podstawowe instytucje i konstrukcje prawne (umowa o pracę, stosunek pracy) mają naturę zobowiązaniową.

Trudno oprzeć się wrażeniu, że wskazane twierdzenia na temat publicznoprawnej proweniencji i istoty prawa pracy nasuwają skojarzenia z demonami z przeszłości oraz pomysłami i praktykami korporacyjnymi czy wręcz ideologią reżymów autorytarnych i totalitarnych, takich jak stalinizm i faszyzm, co skłania do wyrażenia przekonania, że nie powinny one mieć i nie mają szans na szerszą akceptację i realizację.

Pomysł, by zmierzać w stronę prawa zatrudnienia jest o tyle mało realny i mało groźny, że trudno sobie wyobrazić, by w przewidywalnym okresie został w miejsce Kodeksu pracy uchwalony Kodeks zatrudnienia. Uchwalenie takiego kodeksu wymagałoby między innymi przebudowy całej dotychczasowej aparatury pojęciowej naszych regulacji prawnych, 
co jest nieracjonalne. Ponadto niepodobna zakwestionować tezy, że także $\mathrm{w}$ najbliższej i dalszej przyszłości podstawową formą zatrudnienia i świadczenia pracy $\mathrm{w}$ naszym kraju będzie zatrudnienie pracownicze, a nie pozapracownicze. Nie ma więc powodów (także merytorycznych), by zmieniać utrwaloną $w$ przepisach prawnych i mentalności społecznej nazwę „prawo pracy”. Inną sprawą jest natomiast włączenie do - ewentualnie - nowego kodeksu pracy regulacji zatrudnienia niepracowniczego o charakterze cywilnoprawnym, a także administracyjnoprawnym, co zresztą zostało zaproponowane w projekcie Kodeksu pracy opracowanym przez wspomnianą wcześniej Komisję do spraw kodyfikacji prawa pracy. Nie jest to zresztą sprawa zupełnie nowa, bo o tzw. ekspansji prawa pracy czy też o rozciągnięciu jego unormowań prawnych także na inne dziedziny prawa, mówiono w naszej doktrynie prawa pracy już dziesiątki lat temu. Ponadto w art. 303 k.p. przewidziano obowiązek uregulowania w drodze aktu wykonawczego umowy o pracę nakładczą oraz stworzono płaszczyznę unormowania na tej samej drodze pracy osób stale wykonujących pracę na innej podstawie niż stosunek pracy lub umowa o pracę nakładczą.

Pomysł zastąpienia - w wymiarze pojęciowym i normatywnym - prawa pracy prawem socjalnym wydaje się również mało realny i mało groźny. W szczególności trudno sobie wyobrazić, że uchwalony zostanie w naszym kraju kodeks prawa socjalnego, który łączyłby w swej treści unormowania prawa pracy z unormowaniami prawa zabezpieczenia społecznego. Prawo pracy dotyczy osób wykonujących pracę, natomiast prawo zabezpieczenia społecznego normuje sytuację prawną tych, którzy zaprzestali już wykonywania pracy lub pracy tej z różnych względów nie mogą bądź nie chcą świadczyć. Mamy tu do czynienia z różnymi jakościowo kategoriami i pojęciami społecznymi oraz ekonomicznymi, które co do zasady nie powinny stanowić przedmiotu regulacji tego samego aktu prawnego.

Wspomnieć przy tym warto, że nie jest rzeczą przypadku, iż w prawie unijnym i prawie międzynarodowym (w konwencjach Międzynarodowej Organizacji Pracy) rozdzielane są unormowania dotyczące zabezpieczenia społecznego i prawa pracy (spraw socjalnych w wąskim pojęciu). Prawo pracy jest bowiem związane bezpośrednio ze sferą tworzenia dochodu narodowego, natomiast prawo zabezpieczenia społecznego łączy się z decyzjami z zakresu jego wtórnego podziału. W szczególności więc ideologia, potrzeby, pojęcia i konstrukcje prawa zabezpieczenia nie mogą determinować rozwiązań przyjmowanych $\mathrm{w}$ prawie regulującym pracę, a więc tworzenie dochodu (produktu) narodowego. Między innymi emerytura nie może być traktowana jako odłożone wynagrodzenie za pracę, a emeryt uważany za pracownika korzystającego ze zwolnienia z pracy. Wspólne regulowanie $\mathrm{w}$ jednym akcie prawnym materii prawa pracy i prawa zabezpieczenia społecznego może prowadzić do przyjęcia holistycznej 
wizji pracownika-emeryta (pozostającego bez pracy), z negatywnymi konsekwencjami zarówno dla regulacji prawa pracy, jak i prawa zabezpieczenia społecznego. Między innymi z tego również powodu zagrożenie dla przyszłości prawa pracy, o który wspomniałem, jest mało realne.

Na kwestię zagrożeń przyszłości prawa pracy warto spojrzeć także od strony unormowań prawa międzynarodowego i prawa unijnego. Odróżnić przy tym należy w tym zakresie warstwę terminologiczną i normatywną. Regulacje unijne na ogół nie posługują się terminem prawo pracy, a używane są przez nie takie określenia, jak umowa o pracę, stosunek pracy, pracownik, pracodawca. Osobno przy tym normują zagadnienia zabezpieczenia społecznego. Często stanowiły i stanowią źródło i przyczynę ustanawiania określonych regulacji naszego prawa pracy; w przypadku zaś dyrektyw unijnych istnieje obowiązek ich implementowania do naszego prawa wewnętrznego. Ponadto $\mathrm{z}$ reguły takim terminom, jak umowa o pracę, stosunek pracy, pracownik, pracodawca, wynagrodzenie za pracę itp., w prawie unijnym przypisuje się tzw. znaczenie autonomiczne (unijne), nie odpowiadające ściśle terminologii ustawodawstw poszczególnych państw unijnych. Do pewnego stopnia jest podobnie w przypadku międzynarodowego prawa pracy. Prawo to, tak jak prawo unijne, zawiera liczne unormowania materii, które według naszych ujęć krajowych mieszczą się w pojęciowym obszarze prawa pracy. Ustanawiane są w nich standardy prawa pracy, które niejako z natury rzeczy nie mogą ulegać koniunkturalnym zmianom czy modyfikacjom. Ich powszechnością i trwałością zainteresowane są zwłaszcza najbogatsze i najsilniejsze państwa Unii Europejskiej, bo prowadzi to do wyrównywania warunków konkurencji i ograniczania tzw. dumpingu socjalnego, a jednocześnie ich rządy muszą liczyć się ze stałym i mocnym naciskiem ze strony świata pracy, co nie pozwala im na jakieś poważniejsze wycofywanie się z uczynionych wcześniej koncesji na jego rzecz. W konsekwencji nie tylko związanie naszego kraju regulacjami międzynarodowego prawa pracy, ale zwłaszcza przynależność do Unii Europejskiej sprawiaja, że regulacje te i prawo unijne nie tylko nie stanowią zagrożenia dla naszego prawa pracy, ale - wręcz przeciwnie - są istotną gwarancją jego dalszego trwania i rozwoju.

Prawo pracy pojmowane jest nie tylko jako określony, wyodrębniony zespół norm prawnych, ale także jako praktyka ich stosowania (zwłaszcza przez sądy), jak również jako część prawoznawstwa w zakresie stosunków pracy i innych stosunków zaliczanych do przedmiotu regulacji prawa pracy i wreszcie jako określony dział dydaktyki, głównie uniwersyteckiej. W związku z tym należałoby się osobno zastanowić nad przyszłością praktyki, nauki i dydaktyki prawa pracy z perspektywy istniejących dla nich zagrożeń. W niniejszym tekście brak jest jednak miejsca na podejmowanie tego typu kwestii. Ograniczę się więc tylko do kilku refleksji ogólnych. 
Z punktu widzenia praktyki orzecznictwa sądowego w sprawach z zakresu prawa pracy za istotne zagrożenie można uznać dążenie do przekreślenia ustrojowej odrębności sądownictwa pracy i zniesienia swoistości postępowania sądowego w tych sprawach. Obserwować też można tendencję do przekazywania w pewnym zakresie spraw należących do przedmiotu prawa pracy na drogę sądownictwa administracyjnego. Obu tym dążeniom należy się zdecydowanie przeciwstawić, gdyż są one groźne z punktu widzenia interesów i ochrony pracowników. W ostatnich latach stan liczbowy specjalistów prawa pracy wyraźnie wzrósł, czemu towarzyszy zjawisko poszerzania się liczby publikacji z tego obszaru. Ograniczeniu ulega stopień równoczesnego zaangażowania nauczycieli akademickich zajmujących się prawem pracy w działalność pozanaukową. Liczyć przy tym można na to, że wzrostowi liczby publikacji towarzyszyć będzie z czasem także wzrost ich naukowego poziomu i wartości, zgodnie z prawidłowością, że ilość przechodzi w jakość. Należy oczekiwać, że w przyszłości rozwojowi naszej nauki prawa pracy nic nie zagrozi i stanie się ona nie tylko konsumentem cudzych dokonań, lecz jej nowe myśli i osiągnięcia badawcze będą atrakcyjne także w wymiarze europejskim, stanowiąc nasz wkład w rozwój Unii Europejskiej. Gdy idzie o prawo pracy jako rodzaj działalności dydaktycznej, to pewnego zagrożenia dla niego upatrywałbym $\mathrm{w}$ swoistej jego parcelacji. Polega ona na tym, że zamiast prowadzić zajęcia z prawa pracy w pełnym wymiarze, z uwzględnieniem całości materii, którą ono obejmuje, ogranicza się liczbę godzin zajęć dydaktycznych $\mathrm{z}$ tego przedmiotu i wprowadza niejako $\mathrm{w}$ to miejsce zajęcia fakultatywne, traktujące o wybranych problemach. W mojej ocenie, w praktyce prowadzi to raczej do obniżenia poziomu zajęć i wymagań niż do podwyższenia i ugruntowania wiedzy na temat prawa pracy wśród studentów.

\section{The Future of Labour Law in View of Existing Threats to its Development}

\section{Summary}

The analysis of dangers to labour law given by the author takes into account following phenomena: the modernization of the economic structure of contemporary societies, the change in the sphere of the state tasks as well as the opinions of legal doctrine. The analysis includes historical references, especially towards the practices of Stalin (Soviet) epoch and to the Jugoslav self-government system. Author concludes that neither the change of production methods nor the state tasks increase or rise in the number of civil servants as well as appearance of new doctrines, ideologies and conceptions do not pose a significant threat to the existence or development of labour law seen in its different dimensions, i.e. as a special complex of rules or particular practice or special subject of research and teaching. 